\title{
PENGARUH LINGKUNGAN BELAJAR TERHADAP TINGKAT KONSENTRASI BELAJAR SISWA PADA MATA PELAJARAN AKIDAH AKHLAK DI MAN 2 PALEMBANG
}

\author{
Ratih Novianti \\ Guru Pendidikan Agama Islam SDN 159 Palembang \\ Muh Misdar, Helen Sabera Adib. Dosen UIN Raden Fatah Palembang \\ Email : ratihnoviantiguntur96@gmail.com
}

\begin{abstract}
ABSTRAK
Penelitian ini bertujuan untuk mengetahui pengaruh lingkungan belajar terhadap tingkat konsentrasi belajar siswa. Pendekatan yang digunakan dalam penelitian ini adalah kuantitatif dengan jenis penelitian kuantitatif deskriptif. Subjek penelitian ini berjumlah 149 siswa yang terdiri dari siswa kelas X. Penentuan subyek penelitian ini ditentukan dengan mengambil sampel secara acak yang menggunakan teknik sampling purposive sample. Teknik pengumpulan data yang digunakan adalah skala likert. Instrumen yang digunakan adalah skala Lingkungan belajar dan skala konsentrasi belajar. Validasi instrumen dilakukan dengan validasi ahli.

Teknik analisis data yang digunakan pada penelitian ini menggunakan analisis statistik deskriptif. Hasil penelitian menunjukan bahwa Lingkungan belajar siswa kelas X di MAN 2 Palembang sebanyak 29 (65,90\%) siswa berada pada kategori tinggi, 1 $(2,28 \%)$ siswa berada pada kategori sedang, dan $14(31,81 \%)$ siswa berada pada kategori Rendah, Konsentrasi belajar siswa kelas X di MAN 2 Paelembang sebanyak 29 $(65,90 \%)$ siswa berada pada kategori Tinggi, $2(4,54 \%)$ siswa berada pada kategori sedang, $13(29,54 \%)$ siswa berada pada kategori Rendah.

Pengaruh lingkungan belajar terhadap tingkat konsentrasi belajar siswa pada mata pelajaran akidah akhlak di MAN 2 Palembang " $r$ " / rn =0,304 < 0,90 > 0,393. Ini berarti bahwa hipotesis alternatif (Ha) terbukti atau dapat di terima dan hipotesis nihil ditolak (H0) artinya terdapat pengaruh yang signifikan Antara lingkungan belajar terhadap tingkat konsentrasi belajar siswa di MAN 2 Palembang.
\end{abstract}

Kata kunci: lingkungan belajar, konsentrasi belajar siswa 


\section{PENDAHULUAN}

Proses belajar mengajar adalah suatu kegiatan yang dilakukan secara sadar dan sengaja dan merupakan suatu aspek dari lingkungan sekolah yang diorganisasi. Proses belajar mengajar mempunyai makna dan pengertian yang lebih luas dari pada pengertian mengajar. Dalam proses belajar mengajar tersirat adanya satukesatuan kegiatan yang tak terpisahkan antara siswa yang belajar dan guru yang mengajar. Antara kegiatan ini terjalin interaksi yang saling menunjang. Belajar mengajar adalah suatu kegiatan yang bernilai edukatif. Nilai edukatif mewarnai interaksi yang terjadi antara guru dengan anak didik. ${ }^{1}$ Adapun menurut UndangUndang No. 20 tahun 2003 Bab I Pasal 1 Ayat 1 yang berbunyi:

"Pendidikan adalah usaha sadar dan terencana untuk mewujudkan suasana belajar dan proses pembelajaran agar peserta didik aktif mengembangkan potensi dirinya untuk memiliki kekuatan spiritual keagamaan, pengendalian diri, kepribadian, kecerdasan, akhlak mulia, serta keterampilan yang diperlukan dirinya, masyarakat, bangsa dan negara. (Pengertian pendidikan, bab 1, 1 (1) Undang-Undang Sisdiknas no 20/2003)." 2

Oleh karena itu, pembaruan pendidikan harus selalu dilakukan untuk meningkatkan kualitas pendidikan suatu bangsa. Seorang guru harus selalu belajar meningkatkan kualitas dirinya. Perkembangan zaman memungkinkan siswa mendapat informasi dari berbagai sumber sehingga siswa menjadi lebih cedas dan kritis. Hal inilah yang menuntut seorang guru harus selalu belajar. Menurut Drs. Slameto, belajar adalah suatu proses usaha yang dilakukan individu untuk memperoleh suatu perubahan tingkah laku yang baru secara keseluruhan, sebagai hasil pengalaman individu itu sendiri dalam interaksi dengan lingkungannya.

Belajar adalah serangkaian kegiatan jiwa raga untuk memperoleh suatu perubahan tingkah laku sebagai hasil dari pengalaman individu dalam interaksi dengan lingkungannya yang menyangkut kognitif, afektif dan psikomotor. ${ }^{3}$ Menurut Ernest R. Hilgard (dalam buku Rohmalina Wahab,2015) belajar merupakan proses perbuatan yang dilakukan dengan sengaja, yang kemudian menimbulkan perubahan yang keadaannya berbeda dari perubahan yang timbul oleh lainnya. Jadi, ditarik kesimpulan dari pengertian belajar diatas maka dapat disimpulkan bahwa belajar adalah semua aktivitas mental atau pkisis yang dilakukan oleh seseorang sehingga menimbulkan perubahan tingkah laku yang berbeda antara sesudah belajar dan sebelum belajar. ${ }^{4}$

\footnotetext{
${ }^{1}$ Syaiful Bahri Djamarah dan Aswan Zain, Strategi Belajar Mengajar, (Jakarta : Rineka Cipta, 2010),. hlm.1

${ }^{2}$ Rusmaini, Ilmu Pendidikan, (Palembang : Grafika Telindo Press,2014),. hlm.2

${ }^{3}$ Syaiful Bahri Djamarah,Op.Cit,. hlm.13

${ }^{4}$ Rohmalina Wahab, Psikologi Belajar (Jakarta :Pt. Rajagrafindo Persada.2015). hlm. 18
} 
Belajar merupakan suatu proses yang tidak akan pernah berhenti selama manusia itu hidup di bumi. Tidak akan pernah manusia yang mendapat sukses tanpa melalui proses belajar, karena didalam belajar inilah manusia menemukan pengetahuan dan pengalaman yang bau. Tiap situasi belajar akan dihadapi secara utuh oleh orang yang belajar sebagai individu yang utuh pula. Itulah sebabnya di dalam situasi yang berbeda setiap hari, maka pelajaran atau permasalahan yang dihadapi akan berbeda pula tergantung cara dan failitas belajar yang ada dan tersedia. ${ }^{5}$

Ada beberapa faktor yang mempengaruhi pendidikan di sekolah yaitu kurikulum, guru, metode pengajaran, fasilitas, lingkungan dan siswa itu sendiri. Lingkungan menjadi berperan penting ketika keberadaannya menjadi faktor penentu dimana faktor yang lain sudah melengkapi pendidikan itu sendiri. Ada tiga lingkungan utama dalam suatu pendidikan yakni keluarga (pendidikan yang terjadi dalam lingkungan keluarga berlangsung alamiah dan wajar serta disebut pendidikan informal), sekolah (pendidikan disekolah adalah pendidikan yang secara sengaja dirancang dan dilaksanakan dengan aturan-aturan ketat, seperti harus berjanjang dan berkesinambung, sehingga disebut pendidikan formal) dan masyarakat (pendidikan dilingkungan masyarakat tidak dipersyaratkan berjenjang dan berkesinambungan dengan aturan-aturan yang lebih longgar sehinnga disebut pendidikan non formal). ${ }^{6}$

Lingkungan adalah suatu yang ada di alam sekitar yang memiliki makna dan pengaruh tertentu kepada individu. Lingkungan sekolah diusahakan senyaman mungkin pada setiap sekolah, hal ini dapat membantu konsentrasi siswa lebih baik. Lingkungan belajar yang baik adalah lingkungan yang menantang dan merangsang peserta didik untuk belajar, memberikan rasa aman dan kepuasan serta mencapai tujuan yang di harapkan. ${ }^{7}$ Jadi lingkungan belajar ini merupakan suatu hal yang sangat penting dalam mendukung suatu proses pembelajaran supaya berjalan dengan efektif dan efisien.

Dalam Kamus Besar Bahasa Indonesia ditemukan kosakata "Konsentrasi" di situ diartikan sebagai upaya pemusatan perhatian atau pikiran pada satu hal. Konsentrasi kemudian dapat dipahami sebagai pemusatan fungsi jiwa terhadap sesuatu masalah atau objek. Perhatian itu sendiri merupakan pemilihan rangsangan yang datang dari lingkungan. Perhatian adalah keaktifan dari jiwa yang diarahkan kepada suatu objek didalam maupun diluar. Dalam belajar diperlukan konsentrasi

${ }^{5}$ Misdar, M., Idi, A., Isnaini, M., Mardeli, M., Zulhijra, Z., \& Syarnubi, S. (2017). PROSES PEMBELAJARAN DI PROGRAM STUDI PENDIDIKAN AGAMA ISLAM FITK UIN RADEN FATAH PALEMBANG. Tadrib: Jurnal Pendidikan Agama Islam, 3(1), 52-74.

${ }^{6}$ Sudarwan Danim Dkk, Psikologi Pendidikan (Dalam Persepektif Baru), (Bandung: Alfabeta,2011),. hlm. 163-164

${ }^{7}$ Syaiful Bahri Djamarah Dan Aswan Zain, Op.Cit,.hlm. 29 
dalam perwujudan perhatian terpusat. Pemusatan perhatian tertuju pada sesuatu objek terentu dengan mengabaikan masalah-masalah lain yang tak diperlukan. ${ }^{8}$

Menurut Syaiful Bahri Djamarah konsentrasi (pemusatan perhatian) adalah pemusatan fungsi jiwa terhadap sesuatu masalah atau objek dengan mengosongkan pikiran dari hal-hal lain, yang dianggap menggangu. ${ }^{9}$ Menurut Thursan Hakim konsentrasi dapat diartikan sebagai suatu proses pemusatan pikiran terhadap objek tertentu. ${ }^{10}$ Pada dasarnya konsentrasi merupakan kemampuan seseorang untuk mengendalikan kemauan, pikiran, perasaan. Jadi konsentrasi adalah memusatkan fungsi jiwa terhadap suatu objek yang diperhatikan siswa dan suatu pemusatan perhatian, pikiran dan perbuatan pada suatu objek yang sedang dipelajari dan mengabaikan segala hal yang tidak berkaitan dengan objek yang sedang dipelajari. Dalam suatu proses belajar konsentrasi itu merupakan salah satu faktor terpenting dalam mengikuti suatu proses pembelajaran supaya proses pembelajaran itu tercapai dan berhasil.

Berdasarkan observasi awal saya di MAN 2 PALEMBANG, pada tanggal 6 Agustus sampai September 2017, saya mengamati proses kegiatan belajar pada mata pelajaran akidah akhlak yaitu :

Permasalahan saat proses belajar ialah sebagian besar siswa pada saat proses pembelajaran berlangsung siswa tidak fokus pada mata pelajaran yang sedang di jelaskan oleh gurunya di depan kelas, siswa lebih fokus kepada hp masing-masing. Konsentrasi belajar yang ini juga disebabkan oleh beberapa faktor yaitu faktor internal dan eksternal. Faktor internal seperti pertama, siswanya yang memang malas belajar dan memperhatikan materi yang sedang di pelajari. Kedua, siswa yang mudah mengantuk dikelas sehingga sukar menerima pelajaran. Ketiga, sebagian siswa sibuk dengan kesibukannya masing-masing (tidak ada kemauan untuk belajar) seperti ada yang maen hp, ada yang mengobrol, membaca novel sehingga perhatianya tidak ke materi yang dipelajari. dan faktor eksternalnya pertama dari sarana dan prasarana tidak memadai seperti kondisi lingkungan kelas yang sempit dan tidak memiliki AC atau kipas angin sehingga anak didik lebih mementingkan keluar kelas dari pada mengikuti pelajaran di dalam kelas. Kedua cara guru yang mengajar tidak menarik, hanya menggunakan metode ceramah, mencatat, dan penugasan.

Berdasarkan fenomena yang telah diuraikan maka diperlukan suatu cara untuk meningkatkan konsentrasi belajar siswa. Ada berbagai cara untuk meningkatkan konsentrasi siswa. Pertama memberikan motivasi kepada siswa. Kedua, membuat bahan pelajaran menarik sehingga mudah dipahami oleh siswa dan juga memberi contoh yang relevan dengan pelajaran yang sedang dipelajari.

\footnotetext{
${ }^{8}$ Anggota IKAPI, Rahasia Sukses Belajar, (Jakarta :Rineka Cipta, 2002),. hlm. 15

${ }^{9}$ Syaiful Bahri Djamarah, Op.Cit, (Jakarta : Rineka Cipta, 2011),. hlm. 97

${ }^{10}$ Thursan Hakim. Mengatasi Gangguan Konsentrasi,(Jakarta: Puspa Swara, 2002),. hlm. 1
} 
Ketiga, mempersiapkan alat bantu belajar. Keempat, menciptakan lingkungan belajar yang kondusif dan menyenangkan.

\section{METODE PENELITIAN}

\section{A. Jenis dan pendekatan penelitian}

Jenis penelitian ini menggunakan penelitian kuantitatif deskriptif. Pendekatan yang digunakan peneliti adalah kuantitatif. Penelitian kuantitatif adalah penelitian yang digunakan untuk menjawab permasalahan melalui teknik pengukuran cermat terhadap variabel-variabel tertentu, sehingga menghasilkan simpulan-simpulan yang dapat digeneralisasikan, lepas dari konteks waktu dan situasi serta jenis data yang dikumpulkan terutama data kuantitatif. Penelitian deskriptif adalah penelitian yang dilakukan untuk mengetahui nilai variabel mandiri, baik satu variabel atau lebih (independen) tanpa membuat perbandingan atau menghubungkan dengan variabel lain ${ }^{11}$. Penelitian kuantitatif banyak digunakan terutama untuk mengembangkan teori dalam suatu disiplin ilmu. Penggunaan pengukuran disertai analisis secara statistik didalam penelitian mengimplikasikan bahwa penelitian ini menggunakan metode kuantitatif. ${ }^{12}$

\section{B. Jenis dan sumber data}

Sumber data adalah semua sumber baik berupa data, bahan, atau orang yang diperlukan dalam penelitian. Sumber data dalam penelitian ini meliputi sumber data primer dan data sekunder. Data primer adalah data yang diperoleh langsung dari subjek penelitian dengan menggunakan alat pengukur atau alat pengambilan data langsung pada subjek sebagai sumber informasi yang dicari. Data sekunder adalah data yang diperoleh lewat pihak lain, tidak langsung diperoleh oleh peneliti dari subjek penelitiannya. ${ }^{13}$ Sumber data primer seluruh responden yang ada. Sumber sekunder meliputi sekolah, tata usaha dan guru.

\section{Populasi dan sampel}

\section{Populasi penelitian}

Menurut Sugiyono "Populasi penelitian adalah wilayah generalisasi yang terdiri atas objek/subjek yang mempunyai kualitas karakteristik tertentu yang ditetapkan oleh peneliti untuk dipelajari dan kemudian ditarik kesimpulannya". ${ }^{14}$ Sedangkan menurut Margono "populasi adalah seluruh data yang menjadi perhatian kita dalam suatu ruang lingkup dan waktu yang kita tentukan". Pengertian lain menyebutkan bahwa populasi adalah keseluruhan objek penelitian yang terdiri dari manusia, benda-benda,

\footnotetext{
${ }^{11}$ Sugiono, Metode Penelitian Bisnis, (Bandung : Pusat Bahasa Depdiknas, 2003),. hlm.11

${ }^{12}$ Zainal, penelitian pendidikan, (Bandung : Remaja Rosdakarya, 2012),. hlm.29

${ }^{13}$ Saifuddin Azwar, Metode Penelitian, (Yogyakarta : Pustaka Pelajar,2015),. hlm. 91

${ }^{14}$ Sugiyono,Metode Penelitian Pendidikan Pendekatan Kualitatif, Kuantitatif, Dan $R$ \& D,(Bandung : Alfabeta,2014), hlm.297
} 
hewan, tumbuh-tumbuhan, gejala-gejala, nilai tes atau peristiwa-peristiwa sebagai sumber data yang memiliki karakteristik tertentu didalam suatu penelitian ${ }^{15}$.

Apabila seorang ingin meneliti semua elemen yang ada di wilayah penelitian, maka penelitiannya merupakan penelitian populasi. Populasi penelitian ini adalah seluruh kelas X IIS MAN 2 Palembang tahun ajaran 2017/2018 yang berjumlah 149 siswa terdiri dari 68 siswa laki-laki dan 81 siswa perempuan, untuk lebih jelasnya dapat dilihat pada tabel berikut ini.

Tabel 1.1

Populasi penelitian

\begin{tabular}{|c|c|c|c|c|}
\hline No. & Kelas & Laki-laki & Perempuan & Jumlah Populasi \\
\hline 1 & X IIS 1 & 13 & 24 & 37 \\
\hline 2 & X IIS 2 & 13 & 24 & 37 \\
\hline 3 & X IIS 3 & 19 & 19 & 38 \\
\hline 4 & X IIS 4 & 23 & 14 & 37 \\
\hline & Jumlah & 68 & 81 & 149 \\
\hline
\end{tabular}

Sumber : Tata Usaha MAN 2 Palembang Tahun Ajaran 2017/2018

\section{Sampel Penelitian}

Langkah selanjutnya setelah memperoleh populasi kemudian menentukan yang bertujuan memudahkan dalam meneliti objek penelitian. Menurut Sugiyono "Sampel adalah bagian dari jumlah karakteristik yang dimiliki oleh populasi tertentu". ${ }^{16}$ Sedangkan menurut Margono "sampel adalah sebagian atau wakil populasi yang diteliti dengan menggunakan cara-cara tertentu". ${ }^{17}$ Adapun teknik pengambilan sampel yang digunakan adalah teknik sampel bertujuan atau purposive sample, yakni dilakukan dengan cara mengambil subjek bukan didasarkan strata atas strata, random atau daerah tetapi didasarkan atas adanya tujuan tertentu. ${ }^{18}$ dengan cara memecahkan populasi menjadi beberapa sub populasi berdasarkan perbedaan karakter populasi. Setiap unit populasi dicatat dan tidak boleh tercatat dua kali. Sampel dipilih secara acak untuk masing-masing sub populasi.

Selanjut jika jumlah subjeknya besar dapat diambil antara 10-15\% atau $20-25 \%$, atau lebih tergantung setidak-tidaknya dari : 1. Kemampuan peneliti dilihat dari waktu, tenaga dan dana. 2. Sempit luasnya wilayah pengamatan dari setiap subjek karena hal ini menyangkut banyak

\footnotetext{
${ }^{15}$ Margono, Metodologi Penelitian Pendidikan,(Jakarta : Rineka Cipta,2010)., hlm.118

${ }^{16}$ Ibid

17 Margono, Op.Cit.,hlm.121

${ }^{18}$ Helen Sabera Adib, Metodologi Penelitian, (Palembang : Noerfikri Offset,2016), hlm.36
} 
sedikitnya data. 3. Besar kecilnya resiko yang ditanggung oleh penelti. ${ }^{19}$ Sehubungan dengan besarnya jumlah populasi siswa maka atas pertimbangan waktu, biaya serta kemampuan maka peneliti hanya mengambil sampel $25 \%$ dari jumlah siswa kelas $X$ IIS MAN 2 PALEMBANG berjumlah 149 orang dengan menggunakan Purposive Sample.

Tabel 1.2

Sampel Penelitian

\begin{tabular}{|l|c|c|c|c|c|}
\hline No & Kelas & Jumlah siswa & Jumlah siswi & $\begin{array}{c}\text { Jumlah } \\
\text { populasi }\end{array}$ & $\begin{array}{c}\text { Jumlah sampel } \\
25 \%\end{array}$ \\
\hline 1 & X IIS & 13 & 24 & 3 & 11 orang \\
\hline 2 & X IIS & 13 & 24 & 3 & 11 orang \\
\hline 3 & X IIS & 19 & 19 & 3 & 11 orang \\
\hline 4 & X IIS & 23 & 14 & 3 & 11 Orang \\
\hline \multicolumn{2}{|c|}{ Jumlah } & 68 & 81 & 149 & 44 orang \\
\hline
\end{tabular}

Sumber : data olahan 2017

\section{Teknik Pengumpulan data}

Untuk memperoleh data yang dihasilkan dalam suatu penelitian berkualitas dan sesuai dengan tujuan penelitian tersebut dapat jawabkan maka diperlukan teknik dalam pengumpulan data tersebut. Dalam pengumpulan data ini penulis menggunakan tiga teknik pengumpulan data yaitu teknik observasi, skala likert dan dokumentasi.

a. Observasi

Observasi atau pengamatan dilakukan sesuai dengan kebutuhan penelitian mengingat tidak setiap penelitian menggunakan alat pengumpul data demikian. Pengamatan atau observasi dilakukan memakan waktu yang lebih lama apabila ingin melihat suatu proses perubahan, dan pengamatan dilakukan dapat tanpa suatu

b. Skala Likert

Kuesioner adalah sejumlah pertanyaan tertulis yang digunakan untuk memperoleh informasi dari responden dalam arti laporan tentang pribadinya atau hal-hal yang diketahuinya, dalam penelitian ini jenis angket yang digunakan adalah skala likert. Yaitu sebuah pernyataan diikuti oleh kolom-kolom yang menunjukkan tingkat-tingkatan, misalnya mulai dari selalu sampai ketidak pernah atau skala likert yaitu instrument dalam bentuk suatu pernyataan dan diikuti oleh lima respon

${ }^{19}$ Suharsimi Arikunto, Prosedur Penelitian Suatu Pendekatan Praktik, (Jakarta: Rineka Cipta, 2013),. hlm. 173 
yang menunjukkan tingkatan. ${ }^{20}$ Metode ini digunakan untuk memperoleh data tentang Tingkat konsentrasi warga belajar. Kuesioner ini juga sering disebut sebagai Skala Likert di mana dalam kuesioner tersebut terdapat beberapa macam peryataan yang berhubungan erat dengan masalah penelitian yang hendak dipecahkan, disusun, dan disebarkan keresponden untuk memperoleh informasi dilapangan ${ }^{21}$. Kuesioner ini digunakan untuk menyimpulkan bahwa adakah pengaruh lingkungan belajar tehadap tingkat konsentrasi siswa pada mata pelajaran akidah akhlak di Man 2 Palembang.

c. Dokumentasi

Teknik pengumpulan data dengan dokumentasi ialah pengambilan data yang diperoleh melalui dokumen-dokumen, baik dokumendokumen yang tersedia di lapangan maupun dokumen yang dibuat oleh peneliti. ${ }^{22}$ Data tersebut diperoleh dari kepala sekolah, wali kelas dan guru mata pelajaran tentang nilai, absen siswa dan perilaku siswa. Dokumentasi sebagai pelengkap data misalnya dokumen yang ada disekolah seperti sejarah berdiri dan letak geografis tempat penelitian, visi dan misi tempat penelitian, stuktur organisasi tempat penelitian, keadaan sarana dan prasarana tempat penelitian, keadaan guru dan karyawan tempat penelitian, keadaan siswa tempat penelitian, waktu belajar serta kurikulum pembelajaran.

\section{Validitas Dan Reliabilitas}

a. Validitas

Validitas merupakan derajat ketepatan antara data yang terjadi pada obyek penelitian dengan daya yang dapat dilaporkan oleh peneliti. Menurut Syofian Siregar validitas adalah menunjukan sejauh mana suatu alat ukur mampu mengukur apa yang ingin di ukur. ${ }^{23}$ Dengan demikian data yang valid adalah "Data yang tidak berbeda" antara data yang dilaporkan oleh peneliti dengan data yang sesungguhnya terjadi pada objek peneliti. ${ }^{24}$. Instrumen yang valid berarti alat ukur yang digunakan untuk mendapatkan data (mengukur) itu valid, valid berarti instrumen tersebut dapat digunakan untuk mengukur apa yang seharusnya diukur, uji validitas suatu instrumen dapat dibagi dengan 3 cara yaitu: (1) Pengujian validitas konstrak, (2) Pengujian validitas isi (content validity), (3) Pengujian validitas eksternal ${ }^{25}$

${ }^{20}$ Sugiyono,Metode Penelitian Pendidikan Pendekatan Kualitatif, Kuantitatif, Dan $R \&$ $D$,(Bandung : Alfabeta,2014),.hlm. 180

21 Sukardi, Ph.D, Ibid,. hlm. 76

${ }^{22}$ Helen Sabera Adib, Op.Cit,. hlm. 38

${ }^{23}$ Syofian Siregar, Log.Cit,.H.46

${ }^{24}$ Sugiyono, Op.Cit.,H.363

${ }^{25}$ Ibid 
Adapun uji validitas yang digunakan dalam penelitian ini adalah uji validitas konstrak (construct validity). Untuk menguji validitas konstrak, dapat digunakan pendapat para ahli (judgement experts), jumlah tenaga ahli yang digunakan minimal tiga orang. Mungkin para ahli akan memberi keputusan: instrumen dapat digunakan tanpa perbaikan, ada perbaikan, dan mungkin dirombak total.

b. Reliabilitas

Menurut Syofian Siregar, "Reliabilitas adalah untuk mengetahui sejauh mana hasil pengukuran tetap konsisten, apabila dilakukan pengukuran dua kali atau lebih terhadap gejala yang sama dengan menggunakan alat pengukur yang sama pula. ${ }^{26}$ Reliabilitas adalah ketetapan atau tingkat presisi atau suatu ukuran atau alat pengukur. Menurut zainal Arifin "Reliabilitas adalah tingkat atau derajat konsistensi dari suatu instrumen"27.

\section{Teknik Analisis Data}

Menurut Sugiyono mengatakan dalam penelitian kuantitatif, teknik analisis data yang digunakan sudah jelas yaitu diarahkan untuk menjawab rumusan masalah atau pengujian hipotesis yang telah dirumuskan dalam proposal. Karena datanya kuantitatif maka teknik analisis data menggunakan metode statistic dekriptif, yaitu statistik yang digunakan untuk mengganalisis data dengan cara mendeskripsikan atau menggambarkan data yang telah terkumpul sebagaimana adanya tanpa bermaksud membuat kesimpulan yang berlaku untuk umum ${ }^{28}$.

Metode statistik deskriptif yaitu statistik yang digunakan untuk menganalisis data dengan cara menggambarkan atau mendeskripsikan secara lengkap dan mendetail. Teknik analisis data kuantitatif adalah suatu proses pengelolaan data dengan cara mengatur urutan data, mengorganisasikannya kedalam suatu pola, mengkategorikannya dan menguraikannya.

Langkah-langkah mengelolah data penelitian :

a. Untuk mencari persentase pengaruh lingkungan belajar terhadap konsentrasi belajar siswa maka digunakan rumus:

$$
\begin{aligned}
& \mathrm{P}=\frac{F}{N} \times 100 \\
& \text { Keterangan : } \\
& \mathrm{F}=\text { frekuensi yang sedang dicari persentasenya } \\
& \mathrm{N}=\text { Number of cases } \text { (jumlah frekuensi/ banyaknya individu) } \\
& \mathrm{P}=\text { angka persentasi }
\end{aligned}
$$

b. Mencari mean dari variable $\mathrm{X}$ dengan menggunakan rumus :

\footnotetext{
${ }^{26}$ Syofian Siregar, Op.Cit,H.55

${ }^{27}$ Zainal Arifin, Evaluasi Pembelajaran ( Prinsip, Teknik, Dan Prosedur), Bandung :Pt. Remaja Rosdakarya.,H.258

${ }^{28}$ Sugiyono, Op.Cit,. hlm.333
} 


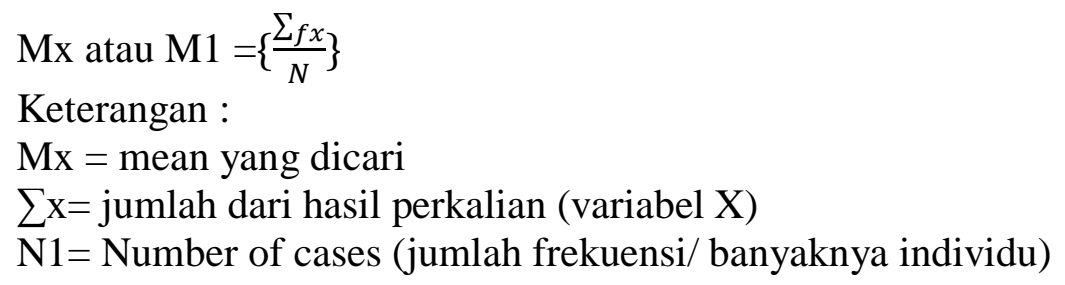

c. Mencari mean dari variable $\mathrm{Y}$ dengan menggunakan rumus :

My atau M1 $=\left\{\frac{\sum_{f y}}{N}\right\}$

Keterangan :

My $=$ mean yang dicari

$\sum \mathrm{y}=$ jumlah dari hasil perkalian (variabel $\mathrm{Y}$ )

N1 = Number of cases (jumlah frekuensi/ banyaknya individu)

d. Mencari standar deviasi dari variable $\mathrm{X}$ menggunakan rumus :

$\mathrm{SD}=\sqrt{\frac{\sum F X^{2}}{N}}$

Keterangan :

SDx = standar deviasi variable $\mathrm{X}$

$\sum \mathrm{X} 2$ = jumlah semuar deviasi, setelah mengalami penguadratan terlebih dahulu.

$\mathrm{N}=$ Number of cases (jumlah frekuensi/ banyaknya individu)

e. Mencari standar deviasi dari variable $\mathrm{X}$ menggunakan rumus :

$\mathrm{SD}=\sqrt{\frac{\sum F X^{2}}{N}}$

Keterangan :

SDx = standar deviasi variable $\mathrm{X}$

$\sum \mathrm{X} 2$ = jumlah semuar deviasi, setelah mengalami penguadratan terlebih dahulu.

$\mathrm{N}$ = Number of cases (jumlah frekuensi/ banyaknya individu)

f. Kemudian setelah didapat mean dan standar deviasi, maka untuk mengetahui tinggi rendahnya pengaruh lingkungan belajar terhadap tingkat konsentrasi belajar siswa yang diperoleh dari penyebaran anket digunakan rumus sebagai berikut :

Tinggi $=\mathrm{Mx}+1$. SD

Sedang $=\mathrm{Mx}-1 . \mathrm{SD}$

$=\mathrm{MX}+1 . \mathrm{SD}$

Rendah $=\mathrm{Mx}-1 . \mathrm{SD}$

g. Selanjutnya untuk menganalisis data tentang pengaruh variable X Dan $\mathrm{Y}$, mengunakan rumus "korelasi product moment", hubungan kedua variabel.

$r_{x y}=\frac{n \sum x y-\left(\sum x\right)\left(\sum y\right)}{\sqrt{\left(n \sum x^{2}-\left(\sum x\right)^{2}\right)\left(n \sum y^{2}-\left(\sum y\right)^{2}\right)}}$

Keterangan

$\mathrm{Rxy}=$ koefisien korelasi antara variabel $\mathrm{X}$ dan $\mathrm{Y}$

$\mathrm{N}=$ jumlah subjek (responden)

$\sum \mathrm{x}=$ jumlah skor item 
$\sum \mathrm{y}=$ jumlah skor total ${ }^{29}$

\section{HASIL PENELITIAN}

\section{A. Lingkungan Belajar Siswa Pada Mata Pelajaran Akidah Akhlak DI MAN 2 Palembang.}

Lingkungan belajar yang dimaksud dalam penelitian ini adalah semua yang ada disekitar sekolah suatu individu yang saling berinteraksi dan saling mempengaruhi satu sama lain. Untuk mengetahui lingkungan belajar di MAN 2 Palembang peneliti menyebar angket kepada siswa yang berjumlah 44 orang siswa yang menjadi sampel dalam penelitian ini. Adapun data mentah dari angket lingkungan belajar di MAN 2 Palembang adalah sebagai berikut :

67456642476472426867686572696772426166686870585968 67726369724270686073724364597363724458

Berdasarkan perolehan skor diatas, maka dapat diketahui nilai tertinggi 73 dan nilai terendah 42. Dan selebihnya tersebar dalam rentang Antara kedua nilai tersebut, disebabkan nilai data mentah sangat bervariasi, maka untuk mengklarifikasikan ke dalam kategori tinggi, sedang dan rendah. Maka skor tersebut disusun dalam tabel distribusi frekuensi sebagai berikut :

Tabel 3.21

Distribusi nilai variabel $\mathrm{X}$ (Lingkungan belajar)

\begin{tabular}{|c|c|c|c|c|c|}
\hline $\mathrm{X}$ & $\mathrm{F}$ & $\mathrm{Fx}$ & $\mathrm{X}$ & $\mathrm{X}^{2}$ & $\mathrm{Fx}^{2}$ \\
\hline 73 & 2 & 146 & 11 & 121 & 242 \\
\hline 72 & 6 & 432 & 10 & 100 & 600 \\
\hline 70 & 2 & 140 & 8 & 64 & 128 \\
\hline 69 & 2 & 138 & 7 & 49 & 98 \\
\hline 68 & 6 & 408 & 6 & 36 & 216 \\
\hline 67 & 4 & 268 & 5 & 25 & 100 \\
\hline 66 & 2 & 132 & 4 & 16 & 32 \\
\hline 65 & 1 & 65 & 3 & 9 & 9 \\
\hline 64 & 2 & 128 & 2 & 4 & 8 \\
\hline 63 & 2 & 126 & 1 & 1 & 2 \\
\hline 61 & 1 & 61 & -1 & 1 & 1 \\
\hline 60 & 1 & 60 & -2 & 4 & 4 \\
\hline 59 & 2 & 118 & -3 & 9 & 18 \\
\hline 58 & 2 & 116 & -4 & 16 & 32 \\
\hline 47 & 1 & 47 & -15 & 225 & 225 \\
\hline 46 & 1 & 46 & -16 & 256 & 256 \\
\hline 45 & 1 & 45 & -17 & 289 & 289 \\
\hline 44 & 1 & 44 & -18 & 324 & 324 \\
\hline 43 & 1 & 43 & -19 & 361 & 361 \\
\hline 42 & 4 & 168 & -20 & 400 & 1600 \\
\hline & & & & & \\
\hline
\end{tabular}

${ }^{29}$ Sugiono, Statistik untuk penelitian, (Bandung : Alfabeta,2010),. Hlm 228 


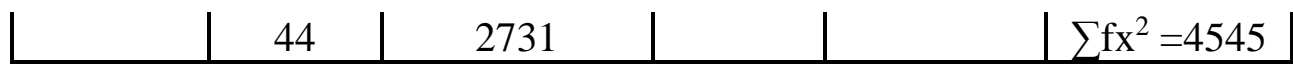

Berdasarkan tabel 2.21 dapat dihitung nilai rata-rata dari lingkungan belajar (X) adalah:

$$
\begin{aligned}
& \mathrm{M}_{\mathrm{x}}=\frac{\sum f x}{N}=\frac{2731}{44}=62,06=62 \\
& \mathrm{SD}_{\mathrm{x}}=\frac{\sqrt{ } \sum f x 2}{N}=\frac{\sqrt{4545}}{44}=\frac{67,42}{44}=1,53=1
\end{aligned}
$$

Setelah diketahui mean skor dan standar deviasi dari angket lingkungan belajar maka selanjutnya adalah menetapkan kategori tinggi, sedang dan rendah (TSR) adapun kategori tersebut sebagai berikut:

Tinggi

$$
\begin{aligned}
& =\mathrm{Mx}+1 .(\mathrm{SD}) \\
= & 62+1 .(1) \\
= & 62+1 \\
= & 63 \text { keatas } \\
\quad & =\mathrm{Mx}-1 .(\mathrm{SD}) \\
= & 62-1 .(1) \\
= & 62-1 \\
= & 61 \\
= & \mathrm{Mx}+1 .(\mathrm{SD}) \\
= & 62+1 .(1) \\
= & 62+1 \\
= & 63
\end{aligned}
$$

Sedang

Jadi untuk kategori sedang Antara 61 - 63

Rendah $=\mathrm{Mx}-1$. (SD)

$$
\begin{aligned}
& =62-1 .(1) \\
& =62-1 \\
& =61 \text { kebawah }
\end{aligned}
$$

Setelah dilaksanakan pada data mentah tentang lingkungan belajar di MAN 2 Palembang, diketahui bahwa 29 responden termasuk dalam kategori tinggi, 1 responden termasuk katagori sedang, dan 14 responden termasuk pada kategori rendah.

\section{Tabel 3.22}

Kategori Tinggi, Sedang dan Rendah lingkungan belajar

\begin{tabular}{|c|c|c|c|}
\hline katagori & Rentang skor & frekuensi & Persentase \\
\hline tinggi & $\geq 63$ & 29 & $\frac{29}{44} \times 100=65,90 \%$ \\
\hline sedang & $61-63$ & 1 & $\frac{1}{44} \times 100=2,28 \%$ \\
\hline rendah & $\leq 61$ & 14 & $\frac{14}{44} \times 100=31,81 \%$ \\
\hline
\end{tabular}

Berdasarkan kategori skor tinggi, sedang, dan rendah tabel 3.22, lingkungan belajar di MAN 2 Palembang mendapatkan frekuensi terbanyak 
pada kategori tinggi yakni 65,90\% maka dapat disimpulkan bahwa lingkungan belajar man 2 palembang tergolong baik. Selain itu peneliti juga mengamati lingkungan belajar di MAN 2 Palembang itu tergolong cukup baik karena lingkungan belajar MAN 2 Palembang ini interaksi sosial (edukatif) anak didik di sekolah, baik berupa interaksi antar individu (anak didik), individu dengan kelompok (anak didik), dan kelompok dengan kelompok disekolah, dan lingkungan belajar di MAN 2 Palembang ini sebagian siswa ada yang tidak mematuhi aturan misalnya datang terlambat, tidak menggunakan perlengkapan seragam saat upacara. Tetapi saat proses pembelajaran siswa MAN 2 Palembang mengikutinya secara baik.

Di MAN 2 Palembang juga sarana dan prasarananya cukup baik. Walaupun lingkungan belajar MAN 2 Palembang ini berdekatan dengan Universitas Islam Negeri Raden Fatah, Ma Al-Fatah Dan Puskesmas UIN tetapi lingkungannya cukup baik cara siswa bersosialisasi juga baik. Dari hasil angkat dan observasi tersebut peneliti menyimpulkan bahwa lingkungan belajar di Man 2 Palembang ini masih tergolong baik karena dari hasil angket menyatakan bahwa siswa ini dalam keadaan tinggi, sedangkan dari hasil observasi peneliti mengatakan bahwa siswa di MAN 2 palembang juga cukup baik, walaupun ada yang tidak menaati aturan yang dibuat sekolah tersebut namun semua itu tidak menjadikan lingkungan belajar Man 2 Palembang itu buruk karena yang tidak menaati aturan ( tata tertib) itu lebih sedikit di banding dengan yang patuh terhadap tata tertib.

\section{B. Tingkat Konsentrasi Belajar Siswa Pada Mata Pelajaran Akidah Akhlak Di Man 2 Palembang}

Untuk mengetahui Tingkat konsentrasi belajar di MAN 2 Palembang, maka peneliti menyebar angket yang terdiri dari 20 item pernyataan yang diajukan kepada 44 orang siswa yang menjadi sampel dalam penelitian ini. Adapun data mentah dari angket tingkat konsentrasi belajar siswa di MAN 2 Palembang adalah sebagai berikut:

72426642426472426867686172696772426166686870726368 67585973724264686063724258597369724270

Berdasarkan perolehan skor diatas, maka dapat diketahui nilai tertinggi 73 dan nilai terendah 42. Dan selebihnya tersebar dalam rentang Antara kedua nilai tersebut, disebabkan nilai data mentah sangat bervariasi, maka untuk mengklarifikasikan ke dalam kategori tinggi, sedang dan rendah. Maka skor tersebut disusun dalam tabel distribusi frekuensi sebagai berikut :

Tabel 4.21

Distribusi nilai variabel Y (konsentrasi belajar siswa) 


\begin{tabular}{|r|r|r|r|r|r|}
\hline Y & F & FY & Y & $Y^{2}$ & $F^{2}$ \\
\hline 73 & 2 & 146 & 11 & 121 & 242 \\
\hline 72 & 8 & 576 & 10 & 100 & 800 \\
\hline 70 & 2 & 140 & 8 & 64 & 128 \\
\hline 69 & 2 & 138 & 7 & 49 & 98 \\
\hline 68 & 6 & 408 & 6 & 36 & 216 \\
\hline 67 & 2 & 134 & 5 & 25 & 50 \\
\hline 66 & 2 & 132 & 4 & 16 & 32 \\
\hline 64 & 4 & 256 & 2 & 4 & 16 \\
\hline 63 & 1 & 63 & 1 & 1 & 1 \\
\hline 61 & 2 & 122 & -1 & 1 & 2 \\
\hline 60 & 1 & 60 & -2 & 4 & 4 \\
\hline 59 & 2 & 118 & -3 & 9 & 18 \\
\hline 58 & 2 & 116 & -4 & 16 & 32 \\
\hline 42 & 8 & 336 & -20 & 400 & 3200 \\
\hline & 44 & 2745 & & & $\sum \mathrm{fy}^{2}=4839$ \\
\hline
\end{tabular}

Berdasarkan tabel diatas dapat dihitung nilai rata-rata dari Konsentrasi belajar (Y) adalah:

$$
\begin{aligned}
& \mathrm{M}_{\mathrm{y}}=\frac{\sum f x}{N}=\frac{2745}{44}=62,38=62 \\
& \mathrm{SD}_{\mathrm{y}}=\frac{\sqrt{ } \mathrm{\Sigma} f x 2}{N}=\frac{\sqrt{4839}}{44}=\frac{69,56}{44}=1,58=1
\end{aligned}
$$

Setelah diketahui mean skor dan standar deviasi dari angket lingkungan belajar maka selanjutnya adalah menetapkan kategori tinggi, sedang dan rendah (TSR) adapun kategori tersebut sebagai berikut:

Tinggi

$$
=\mathrm{My}+1 \text {.(SD) }
$$

$$
\begin{aligned}
& =62+1 .(1) \\
& =62+1 \\
& =63 \text { keatas }
\end{aligned}
$$

Sedang

$$
\begin{aligned}
& =62-1 .(1) \\
& =62-1 \\
& =61 \\
& =\mathrm{My}+1 .(\mathrm{SD}) \\
& =62+1 .(1) \\
& =62+1 \\
& =63
\end{aligned}
$$

Jadi untuk kategori sedang Antara 61 - 63

Rendah $\quad=$ My -1 . (SD)

$=62-1 .(1)$

$$
\begin{aligned}
& =62-1 \\
& =61 \text { kebawah }
\end{aligned}
$$


Setelah dilaksanakan pada data mentah tentang tingkat konsentrasi belajar siswa di MAN 2 Palembang, diketahui bahwa 29 responden termasuk dalam kategori tinggi, 2 responden termasuk katagori sedang, dan 13 responden termasuk pada kategori rendah.

Tabel 4.22

Kategori Tinggi, Sedang dan Rendah konsentrasi belajar

\begin{tabular}{|c|c|c|c|}
\hline Katagori & Rentang skor & Frekuensi & Persentase \\
\hline Tinggi & $\geq 63$ & 29 & $\frac{29}{44} \times 100=65,90 \%$ \\
\hline Sedang & $61-63$ & 2 & $\frac{2}{44} x 100=4,54 \%$ \\
\hline Rendah & $\leq 61$ & 13 & $\frac{13}{44} x 100=29,54 \%$ \\
\hline
\end{tabular}

Dengan memperhatikan tabel 4.22 maka dapat diketahui bahwa sebanyak 29 (65,90\%), menyatakan konsentrasi belajar di MAN 2 Palembang tinggi, 2 (4,54\%), menyatakan konsentrasi belajar di MAN 2 Palembang sedang, 13 (29,54\%), menyatakan konsentrasi belajar di MAN 2 Palembang rendah. Berdasarkan kategori skor tinggi, sedang, rendah diatas konsentrasi belajar di MAN 2 Palembang mendapatkan frekuensi terbanyak pada tinggi yakni 65,90\% maka ditarik kesimpulan bahwa konsentrasi belajar di man 2 Palembang tergolong tinggi.

Dari hasil angkat dan observasi tersebut peneliti menyimpulkan bahwa konsentrasi belajar di Man 2 Palembang ini masih tergolong baik karena dari hasil angket menyatakan bahwa siswa ini dalam keadaan tinggi, sedangkan dari hasil observasi peneliti mengatakan bahwa siswa di MAN 2 palembang juga cukup baik, walaupun masih ada siswa yang tidak memperhatikan guru saat menjelaskan dan masih ada juga siswa yang saat tidak mengerti tapi tidak mau bertanya (bersikap pasif di dalam kelas). ${ }^{30}$

\section{Pengaruh lingkungan belajar terhadap tingkat konsentrasi belajar siswa pada mata pelajaran Akidah Akhlak di MAN 2 Palembang}

Untuk mengetahui ada tidaknya pengaruh Antara lingkungan belajar terhadap tingkat konsentrasi belajar siswa pada mata pelajaran Akidah Akhlak di MAN 2 Palembang, maka penulis menggunakan teknik analisis korelasi product momen dengan langkah-langkah sebagai berikut: berdasarkan hasil penyebaran angket kepada 44 responden dengan 20 butir item soal dan alternatif jawaban, berkenaan dengan lingkungan belajar di peroleh data mentah sebagai berikut :

67456642476472426867686572696772426166686870585968 67726369724270686073724364597363724458

${ }^{30}$ Responden, MAN 2 Palembang, 2 mai 2018 
Sedangkan berdasarkan hasil penyebaran angket kepada 44 responden dengan 20 butir item soal dan alternatif jawaban, berkenaan dengan tingkat konsentrasi belajar siswa di peroleh data mentah sebagai berikut :

72426642426472426867686172696772426166686870726368 67585973724264686063724258597369724270

Untuk menganalisis data yang di peroleh dari lingkungan belajar terhadap tingkat konsentrasi belajar siswa pada mata pelajaran akidah akhlak di man 2 Palembang, penulis membuat tabel perhitungan analisis data dengan mencari nilai statistic dasar sebagai berikut :

Tabel 5. 1

Perhitungan untuk memperoleh Angka indeks korelasi Antara variabel X ( pengaruh lingkungan belajar) dan variabel Y (Tingkat Konsentrasi)

\begin{tabular}{|c|c|c|c|c|c|}
\hline No & $X$ & $Y$ & $X Y$ & $x^{2}$ & $y^{2}$ \\
\hline 1 & 67 & 72 & 4824 & 4489 & 5184 \\
\hline 2 & 45 & 42 & 1890 & 2025 & 1764 \\
\hline 3 & 66 & 66 & 4356 & 4356 & 4356 \\
\hline 4 & 42 & 42 & 1764 & 1764 & 1764 \\
\hline 5 & 47 & 42 & 1974 & 2209 & 1764 \\
\hline 6 & 64 & 64 & 4096 & 4096 & 4096 \\
\hline 7 & 72 & 72 & 5184 & 5184 & 5184 \\
\hline 8 & 42 & 42 & 1764 & 1764 & 1764 \\
\hline 9 & 68 & 68 & 4624 & 4624 & 4624 \\
\hline 10 & 67 & 67 & 4489 & 4489 & 4489 \\
\hline 11 & 68 & 68 & 4624 & 4624 & 4624 \\
\hline 12 & 65 & 61 & 3965 & 4225 & 3721 \\
\hline 13 & 72 & 72 & 5184 & 5184 & 5184 \\
\hline 14 & 69 & 69 & 4761 & 4761 & 4761 \\
\hline 15 & 67 & 67 & 4489 & 4489 & 4489 \\
\hline 16 & 72 & 72 & 5184 & 5184 & 5184 \\
\hline 17 & 42 & 42 & 1764 & 1764 & 1764 \\
\hline 18 & 61 & 61 & 3721 & 3721 & 3721 \\
\hline 19 & 66 & 66 & 4356 & 4356 & 4356 \\
\hline 20 & 68 & 68 & 4624 & 4624 & 4624 \\
\hline 21 & 68 & 68 & 4624 & 4624 & 4624 \\
\hline
\end{tabular}




\begin{tabular}{|l|l|l|l|l|l|}
22 & 70 & 70 & 4900 & 4900 & 4900 \\
\hline 23 & 58 & 72 & 4176 & 3364 & 5184 \\
\hline 24 & 59 & 63 & 3717 & 3481 & 3969 \\
\hline 25 & 68 & 68 & 4624 & 4624 & 4624 \\
\hline 26 & 67 & 67 & 4489 & 4489 & 4489 \\
\hline 27 & 72 & 58 & 4176 & 5184 & 3364 \\
\hline 28 & 63 & 59 & 3717 & 3969 & 3481 \\
\hline 29 & 69 & 73 & 5037 & 4761 & 5329 \\
\hline 30 & 72 & 72 & 5184 & 5184 & 5184 \\
\hline 31 & 42 & 42 & 1764 & 1764 & 1764 \\
\hline 32 & 70 & 64 & 4480 & 4900 & 4096 \\
\hline 33 & 68 & 68 & 4624 & 4624 & 4624 \\
\hline 34 & 60 & 60 & 3600 & 3600 & 3600 \\
\hline 35 & 73 & 63 & 4599 & 5329 & 3969 \\
\hline 36 & 72 & 72 & 5184 & 5184 & 5184 \\
\hline 37 & 43 & 42 & 1806 & 1849 & 1764 \\
\hline 38 & 64 & 58 & 3712 & 4096 & 3364 \\
\hline 39 & 59 & 59 & 3481 & 3481 & 3481 \\
\hline 40 & 73 & 73 & 5329 & 5329 & 5329 \\
\hline 41 & 63 & 69 & 4347 & 3969 & 4761 \\
\hline 42 & 72 & 72 & 5184 & 5184 & 5184 \\
\hline 43 & 44 & 42 & 1848 & 1936 & 1764 \\
\hline 44 & 58 & 70 & 4060 & 3364 & 4900 \\
\hline $\mathrm{N}=44$ & $\Sigma \mathrm{X}=2757$ & 2747 & 176299 & $\sum X^{2}=177121$ & $\sum Y^{2}=176349$ \\
\hline & & & & &
\end{tabular}

Berdasarkan tabel 4.1 perhitungan di atas maka telah diketahui unsurunsur sebagai berikut :

$$
\begin{aligned}
& N=44 \\
& \sum X=2757 \\
& \sum Y=2747 \\
& \sum X Y=176299 \\
& \sum X^{2}=177121 \\
& \sum Y^{2}=176349
\end{aligned}
$$

Langkah selanjutnya adalah mencari $\mathrm{r}_{\mathrm{xy}}$ dengan menggunakan rumus

$$
\begin{aligned}
r_{x y} & =\frac{44 \times 176299-(2757)(2747)}{\sqrt{\left(44 \times 177121-(2757)^{2}\right)\left(44 \times 176349-(2747)^{2}\right)}} \\
r_{x y} & =\frac{7,757156-7,573479}{\sqrt{(7,793324-7.601049)(7.759356-7.546 .009)}}
\end{aligned}
$$




$$
\begin{aligned}
& r_{x y}=\frac{0,183677}{\sqrt{(0,192275)(0,213347)}} \\
& r_{x y}=\frac{0,183677}{\sqrt{(0,0410212944)}} \\
& r_{x y}=\frac{0,183677}{0.2025371433} \\
& r_{x y}=0,9068805702 \text { dibulatkan menjadi } 0,906
\end{aligned}
$$

Setelah harga $r_{x y}$ diketahui, maka selanjutnya adalah memberikan interprestasikan terhadap $r_{x y}$ sebagai berikut :

$\checkmark \quad$ Interprestasi secara sederhana : dari perhitungan diatas ternyata angka korelasi Antara variabel X dan variabel Y tidak bertanda negatif berarti diantara kedua variabel tersebut terdapat korelasi positif (korelasi yang berjalan searah).

$\checkmark$ Dengan demikian memperhatikan rxy (yaitu $=0,90$ ), yang berkisar Antara 0,70 - 0,90 berarti korelasi positif Antara variabel X dan Y itu adalah korelasi positif yang kuat atau tinggi.

$\checkmark$ Interprestasi dengan menggunakan table nilai " $\mathrm{r}$ "; $\mathrm{df}=\mathrm{N}-\mathrm{nr}=44-2=$ 42. Dengan memeriksa tabel nilai " $r$ " product moment ternyata bahwa dengan df sebesar 42, pada taraf signifikansi 5\% diperoleh rtabel $=0,304$, sedangkan pada taraf signifikansi $1 \%$ diperoleh rtabel $=0,393$ Maka dapat diketahui bahwa harga rxy jauh lebih besar pada tabel signifikansi 5\% maupun pada taraf $1 \%$ atau $0,304<0,90>0,393$. Demikian hipotesa Nol (H0) ditolak. Berarti terdapat pengaruh yang signifikan Antara lingkungan belajar terhadap tingkat konsentrasi belajar siswa pada mata pelajaran akidah akhlak di MAN 2 Palembang. Kesimpulan yang dapat kita Tarik adalah lingkungan belajar ini sangat berpengaruh dengan tingkat konsentrasi belajar siswa pada mata pelajaran akidah akhlak di man 2 palembang dan sebaliknya semakin buruk lingkungan belajar maka akan berpengaruh buruk terhadap tingkat konsentrasi belajar siswa.

\section{KESIMPULAN}

Pengaruh lingkungan belajar terhadap Tingkat konsentrasi belajar siswa pada mata pelajaran Akidah akhlak di Man 2 Palembang, maka dapat di simpulkan sebagai berikut :

1. Lingkungan belajar di MAN 2 Palembang dikategorikan Baik, karena terdapat 29 orang siswa $(65,90 \%)$ yang memberi jawaban dari angket yang disebarkan kepada siswa dengan indikasi tinggi, adapun yang menyatakan bahwa lingkungan belajar di MAN 2 Palembang yang sedang sebanyak 1 orang (2,28\%), dan lingkungan belajar di MAN 2 Palembang yang rendah sebanyak 14 orang $(31,81 \%)$. Sehingga dapat dikatakan 
bahwa lingkungan belajar MAN 2 Palembang memiliki tingkat intensitas yang Tinggi.

2. Tingkat konsentrasi belajar di MAN 2 Palembang dikategorikan Baik, karena terdapat 29 orang siswa $(56,90 \%)$ yang memberi jawaban dari angket yang disebarkan kepada siswa dengan indikasi tinggi, adapun yang menyatakan bahwa tingkat konsentrasi belajar di MAN 2 Palembang yang sedang sebanyak 2 orang (4,54\%), dan tingkat konsentrasi belajar di MAN 2 Palembang yang rendah sebanyak 13 orang (29,54\%). Sehingga dapat dikatakan bahwa tingkat konsentrasi belajar MAN 2 Palembang memiliki tingkat intensitas yang tinggi.

3. Pengaruh lingkungan belajar terhadap tingkat konsentrasi belajar siswa pada mata pelajaran akidah akhlak di MAN 2 Palembang " $r$ " / rn =0,304 $<0,90>0,393$. Ini berarti bahwa hipotesis alternatif $\left(\mathrm{H}_{\mathrm{a}}\right)$ terbukti atau dapat di terima dan hipotesis nihil ditolak $\left(\mathrm{H}_{0}\right)$ artinya terdapat pengaruh yang signifikan Antara lingkungan belajar terhadap tingkat konsentrasi belajar siswa di MAN 2 Palembang.

\section{DAFTAR PUSTAKA}

Adib. Helen Sabera. 2016 Metodologi Penelitian, (Palembang : Noerfikri Offset). Alpianto. 2011. Rahasia Mudah Mendidik Dengan Hati, (Bekasi : Pt Tujuh Samudera Alfath,)

Anggota IKAPI. 2002. Rahasia Sukses Belajar, Jakarta :Rineka Cipta.

Ariwibowo. Mustofa Setyo. 2012. Pengaruh Lingkungan Belajar Terhadap Prestasi Belajar Mahasiswa PPKN Angkatan 2008/2009 Universitas Ahmad Dahlann Semester Ganjil Tahun Akademik 2010/2011. Jurnal Citizenship, Vol. 1 No. 2, Januari 2012.

Azwar, Saifuddin. 2015.Metode Penelitian, (Yogyakarta : Pustaka Pelajar).

Baharuddin. 2007.Psikologi Pendidikan : Refleksi Teoritis Terhadap Fenomena,( Jogjakarta : Ar-Ruzz Media).

Dalyono. 2007. psikologi pendidikan,(Jakarta : Rineka Cipta)

Danim. Sudarwan Dkk. 2011. Psikologi Pendidikan (Dalam Persepektif Baru), Bandung: Alfabeta.

Dimyati dan Mudjiono. 2003. Belajar dan Pembelajaran, (Jakarta: Rineka Cipta). Djamarah. Syaiful Bahri dan Aswan Zain.2010. Strategi Belajar Mengajar, Jakarta : Rineka Cipta.

Djamarah. Syaiful Bahri. 2011. Psikologi Belajar, Ed,Rev.,Cet.3, ( Jakarta : Rineka Cipta).

Hamalik. Oemar. 2005, Metoda Belajar dan Kesulitan-Kesulitan Belajar. Bandung: Tarsito

Hakim. Thursan.2002. Mengatasi Gangguan Konsentrasi,(Jakarta: Puspa Swara).

Hakim,Thursan. 2008. belajar secara Efektif,Cet VI, Jakarta: anggota IKAPI. Margono. 2010.Metodologi Penelitian Pendidikan,(Jakarta : Rineka Cipta). 
Misdar, M., Idi, A., Isnaini, M., Mardeli, M., Zulhijra, Z., \& Syarnubi, S. (2017). Proses Pembelajaran Di Program Studi Pendidikan Agama Islam Fitk Uin Raden Fatah Palembang. Tadrib: Jurnal Pendidikan Agama Islam, 3(1), 52-74.

Psychologymania,2013, indicator konsentrasi belajar. Diakses dari http://www.psychologmania.com/2013/04/indikator-konsentrasibelajar.html?m=1. Pada 5 April 2018, Pukul 22.30 WIB.

Rohani. Ahmad.2010. pengelolaan pengajaran : sebuah pengantar menuju guru frofesional, (jakarta :Rineka Cipta).

Rusmaini.2014.Ilmu Pendidikan.Palembang : Grafika Telindo Press.

Slameto.2010. Belajar Dan Faktor-Faktor Yang Mempengaruhinya, Ed. Rev, Cet.5 .Jakarta:Rineka Cipta.

S Nuramaliana, 2016, konsentrasi belajar dan penyesuaian diri pada kelas vii di SMP Negeri 1 Ciawigebang tahun ajaran 2016/2017, journal bimbingan konseling edisi 9 tahun ke 5 2016.student. uny.ac.id/ojs/.../404029, diakses tanggal 9 april 2018, pukul 22.30

Soemanto, Wasty. 2006.Psikologi Pendidikan,(Jakarta :Rineka Cipta).

Subagyo,P. Joko. 2011, Metode Penelitian Dalam Teori Dan Praktik, (Jakarta: Rineka Cipta)

Sudjana. 1995, Penilaian Hasil Proses Belajar Dan Mengajar, (Cet. Xv), Bandung : Pt. Remaja Rosdakarya.

Sugiono. 2003. metode penelitian bisnis, (bandung : pusat bahasa depdiknas).

Sugiyono. 2014.Metode Penelitian Pendidikan Pendekatan Kualitatif, Kuantitatif, Dan $R$ \& $D$,(Bandung : Alfabeta).

Suharsimi Arikunto,2006. Prosedur Penelitian Suatu Pendekatan Praktik, Jakarta: Rineka Cipta.

Surya, Hendra,2003. Kiat Mengajar Anak Belajar dan Berprestasi, (Jakarta: PT Elex Media Komputindo).

Suwardi dan Daryanto. 2017, Manajemen peserta didik, (Yogyakarta : Gava media).

Syamsuddin. Abin Makmun, Psikologi Kependidikan Perangkat Sistem Pengajaran Modul. Bandung: Remadja Rosdakarya,2005.

Tohirin.2011. Psikologi Pembelajaran Pendidikan Agama Islam, Ed.1, cet.4 ( Jakarta : RajaWali pers).

Uno, Hamzah B dan Nurdin Mohammad.2012. belajar dengan pendekatan PAIKEM :Pembelajaran aktif, Inofatif, Lingkungan, Kreatif, Efektif, Menarik,(Jakarta : Bumi Aksara, ).

Wahab. Rohmalina. 2015. Psikologi Belajar. Jakarta :Pt. Rajagrafindo Persada.

Yusuf. Syamsu.Dkk.2011. perkembangan peserta didik mata kuliah dasar profesi (MKDP) Bagi para mahasiswa calon guru dilembaga pendidikan tenaga kependidikan, cet.2, (Jakarta : PT Raja Grafindo Persada).

Zainal. 2012.penelitian pendidikan, (Bandung : Remaja Rosdakarya) 